\title{
Quantification of free and metal-complexed cyanide by tetrathionate derivatization
}

\author{
Alexey Kamyshny Jr , Harry Oduro \& James Farquhar
}

To cite this article: Alexey Kamyshny Jr , Harry Oduro \& James Farquhar (2012) Quantification of free and metal-complexed cyanide by tetrathionate derivatization, International Journal of Environmental Analytical Chemistry, 92:13, 1506-1517, DOI: 10.1080/03067319.2011.561339

To link to this article: https://doi.org/10.1080/03067319.2011.561339

曲 Published online: 20 Jan 2012.

Submit your article to this journal $\pi$

Џ Article views: 144

Q View related articles $\asymp$

Citing articles: 4 View citing articles 


\title{
Quantification of free and metal-complexed cyanide by tetrathionate derivatization
}

\author{
Alexey Kamyshny $\mathrm{Jr}^{\mathrm{ab} *}$, Harry Oduro and James Farquhar ${ }^{\mathrm{a}}$ \\ ${ }^{a}$ Department of Geology and ESSIC, University of Maryland, College Park, Maryland, USA; \\ ${ }^{b}$ Max Planck Institute for Marine Microbiology, Bremen, Germany
}

(Received 12 September 2010; final version received 24 January 2011)

\begin{abstract}
A sensitive and robust method for detection of free and metal-complexed cyanide in solutions is described. The method does not require a distillation step and is applicable for both low ionic strength and sea-water samples. The method is based on the reaction of cyanide with potassium tetrathionate followed by highperformance liquid chromatography (HPLC) separation and UV detection of formed thiocyanate. The detection limit of the method is $250 \mathrm{nmol} \mathrm{L}^{-1}$ cyanide $\left(6.5 \mu \mathrm{g} \mathrm{L}^{-1} \mathrm{CN}^{-}\right)$without a pre-concentration step. Storage for three days does not significantly change the results. The sum of free and weak metal-complexed cyanide can be measured by tetrathionate derivatization at a $\mathrm{pH}$ of 10 . The sum of free, weak metal-complexed cyanide, iron(II) and iron(III)-complexed cyanides may be measured by tetrathionate derivatization at $\mathrm{pH}$ 4.4. Derivatization requires heating to $90^{\circ} \mathrm{C}$ for $20 \mathrm{~min}$ at $\mathrm{pH}=10$ and for $12 \mathrm{~h}$ at $\mathrm{pH}=4.4$. Weighted mean recoveries for free, iron(II), iron(III), nickel(II), silver(I), Cd(II) and Zn(II) complexed cyanide were in the range of 87 to $112 \%$ and weighted standard deviations were in the range of 1.7 to $10.0 \%$. The method is not applicable for cyanide complexes of gold and cobalt. We illustrate an application of cyanide quantification using pore-waters from the Delaware Great Marsh.
\end{abstract}

Keywords: cyanide; iron-cyanide complexes; metallo-cyanide complexes; tetrathionate; liquid chromatography

\section{Introduction}

In aqueous systems dissolved cyanide exists in the form of free cyanide $\left(\mathrm{CN}^{-}\right)$, hydrogen cyanide $(\mathrm{HCN})$, weak metal-cyanide complexes (e.g. $\mathrm{Cd}(\mathrm{CN})_{4}^{2-}, \mathrm{Zn}(\mathrm{CN})_{4}^{2-}$, $\mathrm{Ag}(\mathrm{CN})_{2}^{-}, \mathrm{Ni}(\mathrm{CN})_{4}^{2-}$, etc.) and strong metal-cyanide complexes $\left(\right.$ e.g. $\mathrm{Fe}(\mathrm{CN})_{6}^{4-}, \mathrm{Fe}(\mathrm{CN})_{6}^{3-}$, $\mathrm{Co}(\mathrm{CN})_{6}^{3-}$, etc.) $[1$ and references therein].

Complex matrices interfere with cyanide concentration analysis by colorimetric, titrimetric or electrochemical techniques. The first step of a typical cyanide analysis is manual distillation. Samples are boiled for one to two hours at $\mathrm{pH}<2$ to release total inorganic cyanide as $\mathrm{HCN}$ and at $\mathrm{pH}$ 4.5-6.0 to release $\mathrm{HCN}$ from free cyanide and weak metal-cyanide complexes [2]. Evolved HCN is trapped in alkaline solution and measured by a variety of different protocols [1 and references therein]. Techniques for analysis of metal-cyanide complexes by liquid chromatography allowed separation and quantification of strong and some weak metal-cyanide complexes with low $\left(\mu \mathrm{g} \mathrm{L}^{-1}\right)$ detection limit [3-8].

*Corresponding author. Email: akamyshn@mpi-bremen.de 
Two main techniques applied to achieve this goal are ion exchange chromatography and reversed-phase ion-pair partition chromatography. Analysis of the weakest metal-cyanide complexes such as $\mathrm{Cd}(\mathrm{CN})_{4}^{2-}$ and $\mathrm{Zn}(\mathrm{CN})_{4}^{2-}$ by chromatographic techniques has not been reported, presumably owing to their low stability. For review of chromatographic techniques for cyanide speciation analysis see [1]. The most sensitive chromatographic technique for quantification of free cyanide (detection limit $8 \mathrm{nmol} \mathrm{L}^{-1}$ ) utilized derivatization with 2,3-naphthalenedicarboxaldehyde, followed by HPLC with fluorescence detection [9].

Cyanide is known to be reactive toward species, which have sulfur-sulfur bonds. Polysulfides react with cyanide in minutes to hours, depending on $\mathrm{pH}$, at $25^{\circ} \mathrm{C}$ and in seconds to minutes at $100^{\circ} \mathrm{C}$ (Equation (1)) [10-13]. Thiosulfate reacts with cyanide three orders of magnitude slower than polysulfides (Equation (2)) [10]. Reaction between thiosulfate and cyanide is catalyzed by $\mathrm{Cu}(\mathrm{II})$ [14 and references therein]. Tetrathionate and higher polythionates react rapidly with cyanide (Equation (3)), and trithionate reacts with cyanide much slower (Equation (4)) [13-15 and references therein]. Colloidal and dissolved elemental sulfur is reactive toward cyanide as well (Equation (5)) $[12,13]$.

$$
\begin{gathered}
\mathrm{S}_{\mathrm{n}}^{2-}+(\mathrm{n}-1) \mathrm{CN}^{-}+\mathrm{H}^{+} \rightarrow(\mathrm{n}-1) \mathrm{SCN}^{-}+\mathrm{HS}^{-} \\
\mathrm{S}_{2} \mathrm{O}_{3}^{2-}+\mathrm{CN}^{-} \rightarrow \mathrm{SO}_{3}^{2-}+\mathrm{SCN}^{-} \\
\mathrm{S}_{\mathrm{n}} \mathrm{O}_{6}^{2-}+(\mathrm{n}-3) \mathrm{CN}^{-}+\mathrm{H}_{2} \mathrm{O} \rightarrow \mathrm{S}_{2} \mathrm{O}_{3}^{2-}+\mathrm{SO}_{4}^{2-}+2 \mathrm{H}^{+}+(\mathrm{n}-3) \mathrm{SCN}^{-} \\
\mathrm{S}_{3} \mathrm{O}_{6}^{2-}+\mathrm{CN}^{-}+\mathrm{H}_{2} \mathrm{O} \rightarrow \mathrm{SO}_{3}^{2-}+\mathrm{SO}_{4}^{2-}+2 \mathrm{H}^{+}+\mathrm{SCN}^{-} \\
\mathrm{S}_{8 \text { (colloidal })}+8 \mathrm{CN}^{-} \rightarrow 8 \mathrm{SCN}^{-}
\end{gathered}
$$

Tetrathionate was selected as a derivatizing agent from the suite of sulfur compounds that are reactive toward cyanide because it is non-toxic, odorless, is commercially available and rapidly reacts with cyanide in the absence of catalysts. Potassium tetrathionate is stable in solid form if stored at $-20^{\circ} \mathrm{C}$. Solutions of potassium tetrathionate are stable for days. Recent development of sensitive and robust chromatographic technique for thiocyanate analysis [16] enabled detection of this anion at submicromolar concentration without significant matrix-related problems. Thiocyanate does not undergo protonation even at slightly acidic conditions as its $\mathrm{pK}_{\mathrm{a}}$ is $-1.1 \pm 0.3$ [17] and it is stable in aqueous solutions.

This communication describes an easy and robust analytical protocol for quantification of free cyanide and metal-complexed cyanide at concentrations below $1 \mu \mathrm{mol} \mathrm{L}^{-1}$ and without the requirement of a distillation step. Cyanide is converted to thiocyanate by reaction with potassium tetrathionate and quantification of thiocyanate is undertaken using liquid chromatography.

\section{Experimental}

\subsection{Materials}

All reagents were at least $98 \%$ pure. $\mathrm{K}_{2} \mathrm{~S}_{4} \mathrm{O}_{6}(99 \%), \mathrm{KSCN}(99 \%), \mathrm{KCN}(98 \%)$, $\mathrm{K}_{4}\left[\mathrm{Fe}(\mathrm{CN})_{6}\right] \times 3 \mathrm{H}_{2} \mathrm{O}(99.5 \%), \mathrm{K}_{3}\left[\mathrm{Fe}(\mathrm{CN})_{6}\right](99 \%), \mathrm{K}\left[\mathrm{Ag}(\mathrm{CN})_{2}\right]$ (purity not specified), 
and $\mathrm{K}\left[\mathrm{Au}(\mathrm{CN})_{2}\right](99.98 \%)$ used for preparation of standards were purchased from SigmaAldrich and used without further purification. $\mathrm{K}_{2}\left[\mathrm{Ni}(\mathrm{CN})_{4}\right] \times x \mathrm{H}_{2} \mathrm{O}(99.99 \%$ metal basis $)$ used for preparation of standards was purchased from Sigma-Aldrich and was dried at $110^{\circ} \mathrm{C}$ for 24 hours. $\mathrm{K}_{3}\left[\mathrm{Co}(\mathrm{CN})_{6}\right], \mathrm{K}_{2}\left[\mathrm{Cd}(\mathrm{CN})_{4}\right], \mathrm{K}_{2}\left[\mathrm{Zn}(\mathrm{CN})_{4}\right]$ were synthesized from $\mathrm{CoCl}_{2} \times 6 \mathrm{H}_{2} \mathrm{O}$ (Sigma-Aldrich, 99\%), $\mathrm{CdSO}_{4}$ (Sigma-Aldrich, 99.99\%) and $\mathrm{Zn}(\mathrm{CN})_{2}$ (Sigma-Aldrich, 98\%), respectively, according to [18]. Fresh tetrathionate solution was prepared daily. "Synthetic" sea water was prepared according to [19] with minor differences: No trace constituents (boric acid, silicate and phosphate) were added, $\mathrm{pH}$ was adjusted to 8.0.

Delaware Great Marsh sediment cores were taken near the Cannon Laboratory of College of Earth, Ocean, and Environment of University of Delaware in Lewes $\left(38^{\circ} 48.006 \mathrm{~N}, 75^{\circ} 11.684 \mathrm{~W}\right)$ on April 14, 2010 and transported to the laboratory. Delaware Great Marsh pore-water was extracted with Rhizon samplers inserted through pre-drilled holes in the core liner (type: CSS, Rhizosphere Research Products, NLWageningen) with a filter pore diameter of $100 \mathrm{~nm}$ [20].

Thiocyanate concentrations were measured by an Agilent Technologies 1200 HPLC system with multiple wavelength UV-visible detector operated at $220 \mathrm{~nm}$. A Nomura Chemical, Japan, Develosil RPAQUEOUS C30 reverse phase column $(150 \mathrm{~mm} \times 4.6 \mathrm{~mm} \times 5 \mu \mathrm{m})$ was used for HPLC separation of thiocyanate. The column was prepared according to protocols described by [16] by pumping $5 \%$ aqueous solution of PEG-20,000 at $0.3 \mathrm{~mL} \mathrm{~min}^{-1}$ rate for at least three hours.

Agilent vials and caps with septa were used for tetrathionate derivatization and highperformance liquid chromatography (HPLC) analysis.

\subsection{Methods}

Two methods (Method I and Method II) were developed for analysis of cyanide speciation in aqueous solutions.

Method I was designed to analyse total cyanide (free and metal-complexed). The first step of Method I is acidification of the sample to increase reactivity of iron-cyanide complexes. A $1 \mathrm{~mL}$ sample was pipetted into a $2 \mathrm{~mL}$ HPLC vial. Acidic buffer $(0.1 \mathrm{~mL}$, $\mathrm{pH}=4.4,200 \mathrm{mM}$ boric acid $/ 200 \mathrm{mM}$ sodium chloride) and potassium tetrathionate solution $(0.1 \mathrm{~mL}, 100 \mathrm{mM})$ were added to the vial; it was closed by screw cap with septa and heated at $90^{\circ} \mathrm{C}$ for $8-16 \mathrm{~h}$. After cooling, the resulting solution was analysed by HPLC. In addition to the Method I, a variant (Method Ia) was applied to samples with high cyanide concentration. One $\mathrm{mL}$ of buffer and $0.1 \mathrm{~mL}$ of $\mathrm{K}_{2} \mathrm{~S}_{4} \mathrm{O}_{6}$ solution were added to $0.1 \mathrm{~mL}$ sample.

In the second method (Method II), a basic buffer $\left(0.1 \mathrm{~mL}, \mathrm{pH}=10.0,100 \mathrm{mmol} \mathrm{L}^{-1}\right.$ boric acid $/ 100 \mathrm{mmol} \mathrm{L}^{-1}$ sodium chloride $/ 88 \mathrm{mmol} \mathrm{L}^{-1}$ sodium hydroxide) was added to a $1 \mathrm{~mL}$ sample in order to prevent reaction between tetrathionate and strong metal-cyanide complexes, followed by addition of and potassium tetrathionate solution $(0.1 \mathrm{~mL}$, $100 \mathrm{mM}$ ). The reaction mixture was kept at $90^{\circ} \mathrm{C}$ for $20 \mathrm{~min}$, before cooling and analysis by HPLC.

Methods I and II were applied to free cyanide (KCN solution), complexes of iron (II) and iron (III) with cyanide $\left(\mathrm{K}_{4}\left[\mathrm{Fe}(\mathrm{CN})_{6}\right]\right.$ and $\mathrm{K}_{3}\left[\mathrm{Fe}(\mathrm{CN})_{6}\right]$, respectively) as well to other metal-cyanide complexes $\left(\mathrm{K}_{2}\left[\mathrm{Zn}(\mathrm{CN})_{4}\right], \quad \mathrm{K}_{2}\left[\mathrm{Cd}(\mathrm{CN})_{4}\right], \quad \mathrm{K}\left[\mathrm{Ag}(\mathrm{CN})_{2}\right], \quad \mathrm{K}_{2}\left[\mathrm{Ni}(\mathrm{CN})_{4}\right]\right.$, $\mathrm{K}\left[\mathrm{Au}(\mathrm{CN})_{2}\right]$ and $\mathrm{K}_{3}\left[\mathrm{Co}(\mathrm{CN})_{6}\right]$. The concentration range of samples analysed by 
Methods I and II was $250 \mathrm{n} \mathrm{mol} \mathrm{L} \mathrm{L}^{-1}-3 \mathrm{mmol} \mathrm{L}^{-1}$ cyanide. Method Ia was applied to $\mathrm{KCN}$, $\mathrm{K}_{4}\left[\mathrm{Fe}(\mathrm{CN})_{6}\right], \mathrm{K}_{3}\left[\mathrm{Fe}(\mathrm{CN})_{6}\right], \mathrm{K}_{2}\left[\mathrm{Zn}(\mathrm{CN})_{4}\right], \mathrm{K}\left[\mathrm{Ag}(\mathrm{CN})_{2}\right]$, and $\mathrm{K}_{2}\left[\mathrm{Ni}(\mathrm{CN})_{4}\right]$ samples with cyanide concentrations in the range of $50 \mu \mathrm{mol} \mathrm{L}^{-1}-3 \mathrm{mmol} \mathrm{L}^{-1}$. All experiments were made in triplicates. Details of analytical procedures are summarized in Table 1.

\section{Results and discussion}

\subsection{Final protocol}

The reactivity of nine cyanide species toward tetrathionate at various conditions was studied. These nine species included free cyanide, four weak metallo-cyanide complexes $\left(\mathrm{K}_{2}\left[\mathrm{Zn}(\mathrm{CN})_{4}\right], \mathrm{K}_{2}\left[\mathrm{Cd}(\mathrm{CN})_{4}\right], \mathrm{K}\left[\mathrm{Ag}(\mathrm{CN})_{2}\right]\right.$, and $\left.\mathrm{K}_{2}\left[\mathrm{Ni}(\mathrm{CN})_{4}\right]\right)$ and four strong metallocyanide complexes $\left(\mathrm{K}_{4}\left[\mathrm{Fe}(\mathrm{CN})_{6}\right], \mathrm{K}_{3}\left[\mathrm{Fe}(\mathrm{CN})_{6}\right], \mathrm{K}\left[\mathrm{Au}(\mathrm{CN})_{2}\right]\right.$, and $\left.\mathrm{K}_{3}\left[\mathrm{Co}(\mathrm{CN})_{6}\right]\right)$. Cyanocomplexes of $\mathrm{Zn}(\mathrm{II})$ and $\mathrm{Cd}(\mathrm{II})$, which have response to tetrathionate treatment similar to the one of free cyanides, will be further referred as 'very weak metallo-cyanide complexes'.

Figure 1 shows principal schemes for analysis of free cyanide and mixtures of metallocyanide complexes. Free cyanide should be analyzed by Method II (Table 1) in the

Table 1. Summary of methods used for determination of metal-complexed cyanide.

\begin{tabular}{lcccccc}
\hline Method & $\begin{array}{c}\text { Sample } \\
\text { volume, } \mu \mathrm{L}\end{array}$ & $\begin{array}{c}\text { Buffer } \\
\text { volume, } \mu \mathrm{L}\end{array}$ & $\begin{array}{c}\mathrm{K}_{2} \mathrm{~S}_{4} \mathrm{O}_{6} \\
\text { solution } \\
\text { volume, } \mu \mathrm{L}\end{array}$ & buffer $\mathrm{pH}$ & $t,{ }^{\circ} \mathrm{C}$ & Reaction time \\
\hline I & 1000 & 100 & 100 & 4.4 & 90 & overnight $(12 \pm 4 \mathrm{~h})$ \\
Ia & 100 & 1000 & 100 & 4.4 & 90 & overnight $(12 \pm 4 \mathrm{~h})$ \\
II & 1000 & 100 & 100 & 10.0 & 90 & 20 min \\
\hline
\end{tabular}

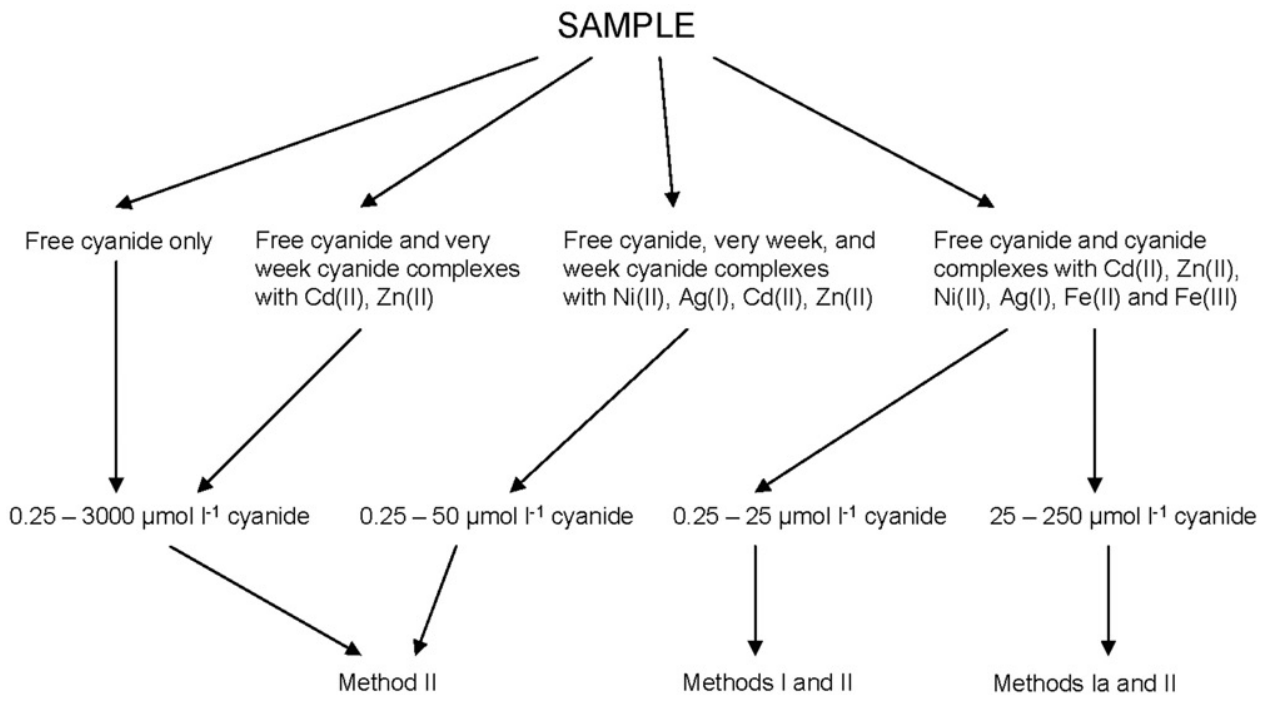

Figure 1. Scheme of analysis of mixtures of free cyanide and various metallo-cyanide complexes. 
concentration range of $250 \mathrm{nmol} \mathrm{L}^{-1}-3 \mathrm{mmol} \mathrm{L}^{-1} \mathrm{CN}^{-}$. Very weak and weak cyanide complexes are indistinguishable from free cyanide and can be analysed by the same method in the concentration ranges of $250 \mathrm{nmol} \mathrm{L}^{-1}-3 \mathrm{mmol} \mathrm{L}^{-1} \mathrm{CN}^{-}$and $250 \mathrm{nmol} \mathrm{L}^{-1}$ $50 \mu \mathrm{mol} \mathrm{L}^{-1} \mathrm{CN}^{-}$, respectively. The cyanide content of strong iron-cyanide complexes should be detected by Method I (Table 1) in the concentration range of $250 \mathrm{nmol} \mathrm{L}^{-1}$ $25 \mu \mathrm{mol} \mathrm{L}{ }^{-1} \mathrm{CN}^{-}$and by Method Ia (Table 1) at concentrations up to $250 \mu \mathrm{mol} \mathrm{L}^{-1} \mathrm{CN}^{-}$. If free cyanide, very weak and/or weak cyanide complexes, and iron-cyanide complexes present in the sample, Method II should be applied as well, and the concentration of ironcomplexed cyanide should be calculated as a difference between results of analyses by the Methods I or Ia and the Method II. The cyanide complex of Co(III) cannot be detected by this protocol. This protocol cannot be applied to system containing cyanide complexes of gold.

The protocol was shown to work for sea water samples and for pore-water samples from a natural salt marsh environment (The Delaware Great Marsh).

\subsection{Precision and accuracy}

Standard deviation is $\leq 10 \%$ for analyses of cyanide content of all metallo-cyanide complexes by all methods in the reported applicability range. Average cyanide recovery by analyses in the reported applicability ranges is $87-112 \%$ (Table 2).

\subsection{Sample storage}

Samples of $\mathrm{KCN}, \mathrm{K}_{4}\left[\mathrm{Fe}(\mathrm{CN})_{6}\right], \mathrm{K}_{3}\left[\mathrm{Fe}(\mathrm{CN})_{6}\right]$, and $\mathrm{K}_{2}\left[\mathrm{Zn}(\mathrm{CN})_{4}\right]$, containing $25 \mu \mathrm{mol} \mathrm{L}{ }^{-1}$ $\mathrm{CN}^{-}$, were stored after derivatization with potassium tetrathionate at $-20^{\circ} \mathrm{C}, 4^{\circ} \mathrm{C}$ and room temperature $\left(25 \pm 2^{\circ} \mathrm{C}\right)$. Samples were analysed immediately after derivatization, after 3 days, and 11-13 days. Analyses of samples stored at room temperature for 3 days were biased relative to results of initial analysis by less than $9 \%$. After 11 days results of most of analysis were reduced by as much as $80 \%$ compared with results of initial analysis. Other storage problems arise from disproportionation of residual tetrathionate. Tetrathionate decomposes in aqueous solutions at near neutral $\mathrm{pH}$ to lower and higher polythionates [21 and references therein]. Pentathionate elutes before thiocyanate with less than a 2 min difference in retention time [12]. At high pentathionate to thiocyanate ratios precise integration of the thiocyanate peak becomes problematic. Storage at $4{ }^{\circ} \mathrm{C}$ does not significantly improve recoveries. Storage at $-20^{\circ} \mathrm{C}$ yields low recovery even after 3 days and is therefore not recommended.

\subsection{Thiocyanate background}

Some aquatic systems contain measurable amounts of thiocyanate. Rong et al. [14] measured $140-260 \mathrm{nmol} \mathrm{L}^{-1}$ of $\mathrm{SCN}^{-}$in seawater samples from the Japanese coast with different levels of pollution. Kamyshny [12] detected $11 \pm 9 \mathrm{nmol} \mathrm{L}^{-1}$ of SCN ${ }^{-}$in North Sea water. Up to $274 \mathrm{nmol} \mathrm{L}^{-1}$ of $\mathrm{SCN}^{-}$was detected in sulfide rich water layer near the bottom of meromictic Fayetteville Green Lake (NY) (Kamyshny-unpublished results). In anoxic aquatic systems natural processes similar to those utilized in this work may occur. Significant concentrations of sulfur species reactive toward cyanide were reported in anoxic natural aquatic systems: Thiosulfate, tetrathionate, and polysulfides were detected 


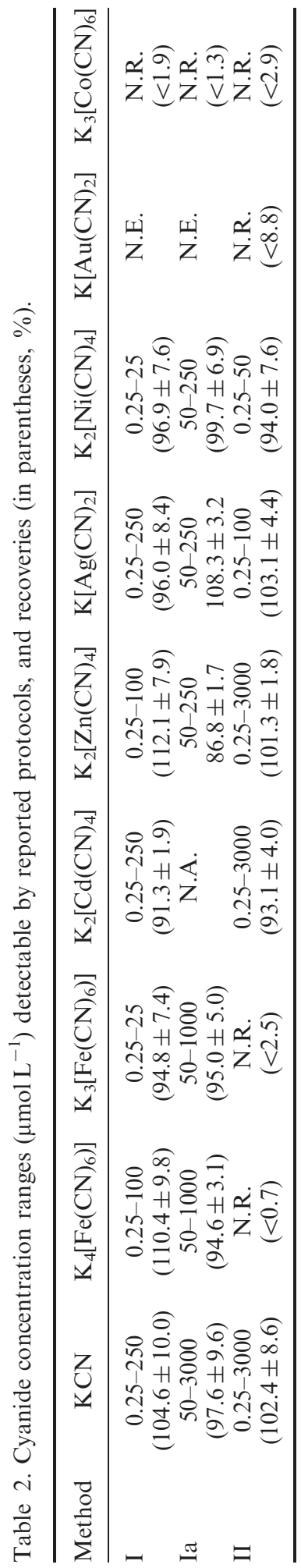


in concentrations of micromoles to hundreds of micromoles per litre in natural aquatic and sedimentary systems [22-27]. These compounds react with cyanide, producing thiocyanate. Measurement of background thiocyanate concentrations is necessary in order to subtract it from the results of analysis for cyanide species.

\subsection{Protocol application at the field conditions}

Tetrathionate may be added to the sample immediately after collection. However sample should be heated before analysis as the reaction between metallo-complexed cyanide and tetrathionate is too slow to convert $\mathrm{CN}^{-}$to $\mathrm{SCN}^{-}$quantitatively at ambient temperature. Another way to apply this method to field samples is to stabilize cyanide by cooling and adjustment of $\mathrm{pH}$ to 12 in dark bottle. $\mathrm{pH}$ should be adjusted accordingly once the samples are returned to the laboratory. In this case, larger amount of buffers should be used, and dilution of the sample will increase the detection limit of analysis.

\subsection{Analytical performance}

Calculations - Average recovery of triplicate samples at each cyanide concentration was calculated, and the concentration interval where the calibration is linear (average recovery of $80-120 \%$ ) was determined. Weighted mean and weighted standard deviation were calculated from results of analysis of triplicate samples at all concentrations in the range of method linear calibration (Table 2). All concentrations are reported as cyanide content of metallo-cyanide complex and not as complex concentration.

Free cyanide - For Method I the linear calibration range for cyanide was $250 \mathrm{nmol} \mathrm{L}{ }^{-1}-250 \mu \mathrm{mol} \mathrm{L}{ }^{-1}$ with recovery of $104.6 \pm 10.0 \%$. For Method Ia, the recovery was $97.6 \pm 9.6 \%$ in the concentration range $50 \mu \mathrm{mol} \mathrm{L}^{-1}-3 \mathrm{mmol} \mathrm{L}^{-1}$ cyanide. For Method II, the recovery in the cyanide concentration range $250 \mu \mathrm{mol} \mathrm{L}^{-1}-3 \mathrm{mmol} \mathrm{L}^{-1}$ was $102.4 \pm 8.6 \%$ (Figure 2a, Table 2). Typical chromatogram for cyanide derivatization is presented in Figure 3a.

Potassium ferrocyanide - For Method I, the linear calibration range for cyanide was $250 \mathrm{nmol} \mathrm{L}{ }^{-1}-100 \mu \mathrm{mol} \mathrm{L}^{-1}$ with recovery of $110.4 \pm 9.8 \%$. For Method Ia, the recovery was $94.6 \pm 3.1 \%$ in the cyanide concentration range $50 \mu \mathrm{mol} \mathrm{L}^{-1}-1 \mathrm{mmol} \mathrm{L}^{-1} \mathrm{CN}^{-}$. For Method II, the cyanide recoveries were below $0.7 \%$ at all concentrations (Figure $2 \mathrm{~b}$, Table 2).

Potassium ferricyanide - For Method I, the linear calibration range for cyanide was $250 \mathrm{nmol} \mathrm{L}^{-1}-25 \mu \mathrm{mol} \mathrm{L}{ }^{-1}$ with recovery of $96.0 \pm 8.4 \%$. For Method Ia, the cyanide recovery was $95.0 \pm 5.0 \%$ in the concentration range $50 \mu \mathrm{mol} \mathrm{L}^{-1}-1 \mathrm{mmol} \mathrm{L}^{-1}$. For Method II, the cyanide recoveries are less than $2.5 \%$ at all concentrations (Figure 2c, Table 2).

Potassium tetracyanozincate (II) - For Method I, the linear calibration range for cyanide was $250 \mathrm{nmol} \mathrm{L}^{-1}-100 \mu \mathrm{mol} \mathrm{L}^{-1}$ with recovery of $112.1 \pm 7.9 \%$. For Method Ia, the cyanide recovery was $86.8 \pm 1.7 \%$ in the concentration range $50 \mu \mathrm{mol} \mathrm{L}^{-1}$ $250 \mu \mathrm{mol} \mathrm{L}^{-1}$. For Method II, the cyanide recovery in the concentration range $250 \mathrm{nmol} \mathrm{L}^{-1}-3 \mathrm{mmol} \mathrm{L}^{-1}$ was $101.3 \pm 1.8 \%$ (Figure 2d, Table 2).

Potassium tetracyanocadmate (II) - For Method I, the linear calibration range for cyanide was $250 \mathrm{nmol} \mathrm{L}^{-1}-250 \mu \mathrm{mol} \mathrm{L}^{-1}$ with recovery of $91.3 \pm 1.9 \%$. For Method II, 

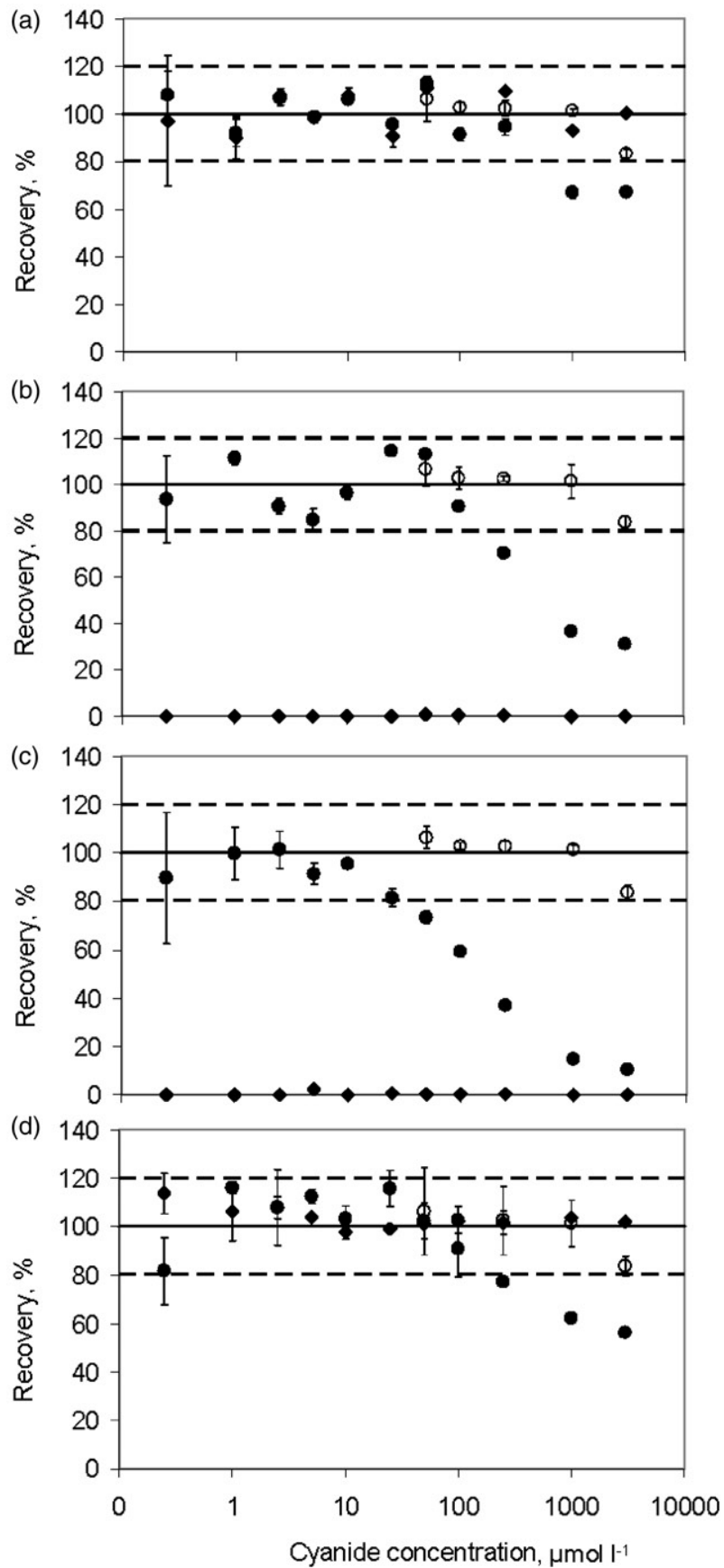

Figure 2. Cyanide recovery by tetrathionate derivatization for $\mathrm{KCN}$ (a), $\mathrm{K}_{4}\left[\mathrm{Fe}(\mathrm{CN})_{6}\right]$ (b), $\mathrm{K}_{3}\left[\mathrm{Fe}(\mathrm{CN})_{6}\right]$ (c), and $\mathrm{K}_{2}\left[\mathrm{Zn}(\mathrm{CN})_{4}\right]$ (d) by Method I (closed circles), Method Ia (opened circles), and Method II (closed diamonds). 


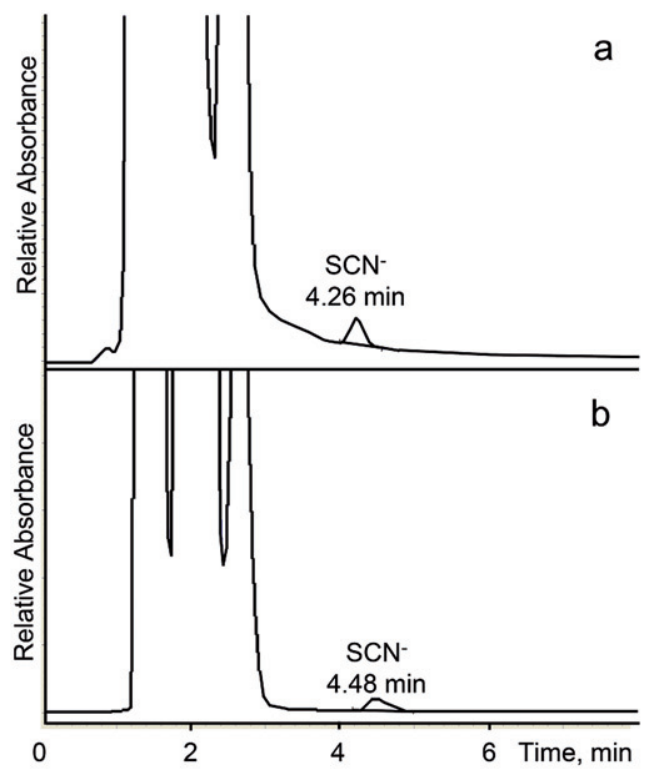

Figure 3. Chromatograms of standard sample containing $10 \mu \mathrm{mol} \mu \mathrm{mol} \mathrm{L}{ }^{-1}$ of free cyanide after derivatization according to Method II (a) and of Delaware Great Marsh pore-water sample $(25 \mathrm{~cm}$ below sediment surface) after derivatization according to Method II (b).

the cyanide recovery in the concentration range $250 \mathrm{nmol} \mathrm{L}^{-1}-3 \mathrm{mmol} \mathrm{L}^{-1} \mathrm{CN}^{-}$was $93.1 \pm 4.0 \%$ (Table 2 ).

Potassium dicyanoargentate (I) - For Method I, the linear calibration range for cyanide was $250 \mathrm{nmol} \mathrm{L}^{-1}-250 \mu \mathrm{mol} \mathrm{L}^{-1} \mathrm{CN}^{-}$with recovery of $96.0 \pm 8.4 \%$. For Method Ia, the recovery was $108.3 \pm 3.2 \%$ in the cyanide concentration range $50-250 \mu \mathrm{mol} \mathrm{L}^{-1}$. For Method II, the cyanide recovery in the concentration range $250 \mathrm{nmol} \mathrm{L}^{-1}$ $100 \mu \mathrm{mol} \mathrm{L}^{-1} \mathrm{CN}^{-}$was $103.1 \pm 4.4 \%$ (Table 2).

Potassium tetracyanonickelate(II) - For Method I, the linear calibration range for cyanide was $250 \mathrm{nmol} \mathrm{L}^{-1}-25 \mu \mathrm{mol} \mathrm{L}^{-1} \mathrm{CN}^{-}$with recovery of $96.9 \pm 7.6 \%$. For Method Ia, the recovery was $99.7 \pm 6.9 \%$ in the cyanide concentration range $50-250 \mu \mathrm{mol} \mathrm{L}^{-1}$. For Method II, the cyanide recovery in the concentration range $250 \mathrm{nmol} \mathrm{L}^{-1}-50 \mu \mathrm{mol} \mathrm{L}^{-1}$ was $94.0 \pm 7.6 \%$ (Table 2).

Potassium dicyanoaurate (I) - For Method I, no linear calibration was found at any concentration range. For the Method II cyanide recoveries are less than $8.8 \%$ at all concentrations (Table 2).

Potassium tetracyanocobaltate(III) - For the Methods I, Ia and II cyanide recoveries were found to be less than $2.9 \%$ at all concentrations (Table 2).

Derivatization in Sea Water Medium - Potassium cyanide, potassium ferrocyanide and potassium ferricyanide solutions with $10 \mu \mathrm{mol} \mathrm{L}^{-1}$ cyanide concentration were prepared in synthetic sea water and analyzed by Methods I and II. Results of analyses for all compounds by Method I were in the $84-113 \%$ range. Results of analysis by Method II were $93 \%$ for free cyanide and $0 \%$ for both iron(II) and iron(III) complexed cyanide.

Analysis of natural samples - Cyanide concentrations were determined in the Delaware Great Marsh pore-waters by Methods I and II at $11 \mathrm{~cm}$ (non-sulfidic, iron(II) rich zone) 
and $25 \mathrm{~cm}\left(5.4 \mathrm{mmol} \mathrm{L}^{-1}\right.$ sulfide concentration) sediment depths. Background thiocyanate concentrations of 1.54 and $3.86 \mu \mathrm{mol} \mathrm{L}^{-1}$ were detected at $11 \mathrm{~cm}$ and $25 \mathrm{~cm}$ depths, respectively. Results of analysis by Method I were 8.58 and $4.13 \mu \mathrm{mol} \mathrm{L}^{-1}$ cyanide at 11 and $25 \mathrm{~cm}$ depths, respectively. Results of analysis by Method II were -0.03 and $3.25 \mu \mathrm{mol} \mathrm{L}{ }^{-1}$ cyanide at 11 and $25 \mathrm{~cm}$ depths, respectively. The negative concentration detected by Method II arises from subtraction of the result of analysis of thiocyanate background concentration from result of analysis. From this data we can calculate that the sum of free and weakly complexed cyanide in the marsh pore-waters is $0.0 \mu \mathrm{mol} \mathrm{L}{ }^{-1}$ at $11 \mathrm{~cm}$ depth and $3.2 \mu \mathrm{mol} \mathrm{L}{ }^{-1}$ at $25 \mathrm{~cm}$ depths. Iron-complexed cyanide concentrations were found to be $8.6 \mu \mathrm{mol} \mathrm{L}{ }^{-1}$ at $11 \mathrm{~cm}$ depth and $0.9 \mu \mathrm{mol} \mathrm{L}{ }^{-1}$ at $25 \mathrm{~cm}$ depth. The fraction of iron-complexed cyanide is $100 \%$ and $21 \%$ at $11 \mathrm{~cm}$ and $25 \mathrm{~cm}$ depths, respectively. Typical Delaware Great Marsh pore-water sample derivatization chromatogram is presented in Figure $3 b$.

\subsection{Explanation of observed recoveries}

Recovery of cyanide by derivatization with tetrathionate depends on two main factors: the stability of metallo-cyanide complex and stability (or solubility) of metallo-thiocyanate complexes. Tetrathionate does not form stable complexes with transition metals.

Stronger metallo-cyanide complexes require lower $\mathrm{pH}$ for dissociation. The strength of metallo-cyanide complexes used in this work increases in the order $\mathrm{Cd}(\mathrm{CN})_{4}^{2-}$ $<\mathrm{Zn}(\mathrm{CN})_{4}^{2-}<\mathrm{Ag}(\mathrm{CN})_{2}^{-}<\mathrm{Ni}(\mathrm{CN})_{4}^{2-}<\mathrm{Au}(\mathrm{CN})_{2}^{-}<\mathrm{Fe}(\mathrm{CN})_{6}^{4-}<\mathrm{Fe}(\mathrm{CN})_{6}^{3-}<\mathrm{Co}(\mathrm{CN})_{6}^{3-}[1]$. Free cyanide and weak metallo-cyanide complexes, $\mathrm{Cd}(\mathrm{CN})_{4}^{2-}, \mathrm{Zn}(\mathrm{CN})_{4}^{2-}, \operatorname{Ag}(\mathrm{CN})_{2}^{-}$, $\mathrm{Ni}(\mathrm{CN})_{4}^{2-}$, react with tetrathionate at $\mathrm{pH}$ 10.0. Stronger complexes, $\mathrm{Au}(\mathrm{CN})_{2}^{-}, \mathrm{Fe}(\mathrm{CN})_{6}^{4-}$, and $\mathrm{Fe}(\mathrm{CN})_{6}^{3-}$, react with tetrathionate at $\mathrm{pH}$ 4.4. The strongest complex, $\mathrm{Co}(\mathrm{CN})_{6}^{3-}$, does not react with tetrathionate even at this $\mathrm{pH}$.

The upper limit of detectable cyanide concentrations depends not only on stability of the metallo-cyanide complex, but on stability of respective metallo-thiocyanate complex as well. If thiocyanate produced by the reaction of cyanide and tetrathionate forms a strong complex with cations in solution, the free thiocyanate concentration in sample after derivatization decreases resulting in negative recovery bias.

Silver thiocyanate solubility in water is low $\left(\mathrm{K}_{\mathrm{SP}}=1.33 \times 10^{-12}\right)$. Precipitation of AgSCN produces negative bias for detection of $\mathrm{SCN}^{-}$formed in the reaction of dicyanoargentate (I) with tetrathionate. Sodium chloride was added to buffer in order to compete with formation of the thiocyanate complex or silver thiocyanate precipitate formation: $100-200 \mathrm{mmol} \mathrm{L}^{-1}$ of sodium chloride was added to buffers used in derivatization procedures. As $\mathrm{K}_{\mathrm{SP}}$ of $\mathrm{AgCl}\left(1.77 \times 10^{-10}\right)$ is two orders of magnitude lower than that of $\mathrm{AgSCN}$, the final concentration of $\mathrm{NaCl}$ in the sample $\left(8.33 \mathrm{mmol} \mathrm{L}^{-1}\right)$ allows us to analyse the silver (I) complexed cyanide at concentrations of up to two orders of magnitude lower $\left(100 \mu \mathrm{mol} \mathrm{L}{ }^{-1}\right)$. Solubilities of silver bromide and silver iodide are lower than the solubility of silver thiocyanate. Unfortunately, poor chromatographic separation between millimolar concentrations of these halogen anions and sub-micromolar concentration of thiocyanate restricts their use in buffer preparation. Chloride is a component of mobile phase and it is neither retained on the column nor affects UV detector background.

The strength of water soluble thiocyanate complexes increases in the order $\mathrm{Zn}(\mathrm{II})<\mathrm{Ni}$ (II) $<\mathrm{Cd}(\mathrm{II})<\mathrm{Fe}$ (III) $<<\mathrm{Au}$ (I) [28]. Metallo-thiocyanate complexes are more stable at low 
$\mathrm{pH}$ values than metallo-cyanide complexes owing to relatively low $\mathrm{pK}_{\mathrm{a}}$ of $\mathrm{HSCN}$ [17]. The upper detection limits for $\mathrm{Zn}(\mathrm{II}), \mathrm{Ni}$ (II), $\mathrm{Cd}(\mathrm{II})$, and Fe(III) cyanide complexes are in the range of $25-250 \mu \mathrm{mol} \mu \mathrm{mol} \mathrm{L}{ }^{-1}$ cyanide. Upper detection limit for Method II is higher than upper detection limit of method I for all metallo-cyanide complexes, except $\operatorname{Ag}(\mathrm{CN})_{2}^{-}$, as at $\mathrm{pH}=10.0$ all metals used in this study (except silver) form (hydr)oxides [29]. Relatively strong blood red thiocyanate complex of $\mathrm{Fe}(\mathrm{III}),[\mathrm{Fe}(\mathrm{SCN})]^{2+}$, does not form at $\mathrm{pH}>3$ owing to formation of insoluble $\mathrm{Fe}(\mathrm{OH})_{3}$ (Equation (6)).

$$
[\mathrm{Fe}(\mathrm{SCN})]_{\mathrm{aq}}^{2+}+3 \mathrm{OH}_{\mathrm{aq}}^{-} \rightarrow \mathrm{Fe}(\mathrm{OH})_{3(\mathrm{~s})}+\mathrm{SCN}_{(\mathrm{aq})}^{-}
$$

Dicyanoaurate (I) can not be detected by the described procedure as gold forms strong complex with thiocyanate.

\subsection{Comparison with existing methods of cyanide quantification}

Existing analytical protocols for analysis of free and metallo-complexed cyanide may be separated in two main groups.

The first group includes methods that account for free cyanide in a relatively noncomplex matrix. The most sensitive method is based on derivatization with a fluorescent reagent followed by HPLC with a fluorescence detector [9]. The detection limit for this technique is as low as $6 \mathrm{nmol} \mathrm{L}^{-1}$. Another group of methods for free cyanide quantification includes titrimetry (detection limit $4 \mu \mathrm{mol} \mathrm{L}^{-1}$ ), colorimetry (detection limit $0.8 \mu \mathrm{mol} \mathrm{L}^{-1}$ ), application of an ion-selective electrode (detection limit $2 \mu \mathrm{mol} \mathrm{L} \mathrm{L}^{-1}$ ) and amperometry (detection limit $75 \mathrm{nmol} \mathrm{L}^{-1}$ ) [30]. A significant draw-back of these techniques is the space and time consuming laborious distillation step, which is required for conversion of metallo-complexed cyanide into free cyanide and elimination of complex matrix, such as see-water salts.

In addition, individual metallo-cyanide complexes can be quantified by ion-interaction chromatography. The detection limit for metallo-cyanide complexes varies in the range of 0.4-8 $\mu \mathrm{mol} \mu \mathrm{mol} \mathrm{L}^{-1}$ [6]. These methods [3-8] do not require cyanide distillation or other sample pre-treatment. A combination of ion-interaction chromatography with postcolumn cyanide derivatization allows detection of free cyanide [31]. The draw-back of these techniques is the necessity of synthesis of all of metallo-cyanide complexes and separate HPLC calibrations for each of them.

The analytical protocol presented in this paper combines the advantages of both approaches: it allows analysis of free cyanide as well as metallo-cyanide complexes, does not require a distillation step, and can be applied to complicated matrices like see-water. The detection limit of this method $\left(0.25 \mu \mathrm{mol} \mathrm{L} \mathrm{L}^{-1}\right)$ is lower than detection limit of most of existing techniques, though it is 40 times higher than detection limit for the most sensitive chromatographic technique [9].

\section{Acknowledgements}

This work was supported by funds from Marie Curie Outgoing International Fellowship SULFUTOPES number POIF-GA-2008-219586 and NSF Geobiology and Low Temperature Geochemistry Program grant number - 0843814. We would like to thank George W. Luther and Andrew Madison (University of Delaware) for assistance during sampling of Delaware Great Marsh. 


\section{References}

[1] R.S. Ghosh, D.A. Dzombak, S.M. Drop, and A. Zheng, in Cyanide in Water and Soil, edited by D.A. Dzombak, R.S. Ghosh, and G.M. Wong-Chong (CRC Press, Boca Raton, Florida, 2006).

[2] T. Mansfeldt and H. Biernath, Anal. Chim. Acta 435, 377 (2001).

[3] D.F. Hilton and P.R. Haddad, J. Chromatogr. 361, 141 (1986).

[4] B. Grigorova, S.A. Wright, and M. Josephson, J. Chromatogr. 410, 419 (1987).

[5] P.R. Haddad and N.E. Rochester, J. Chromatogr. 439, 23 (1988).

[6] P.R. Haddad and C. Kalambaheti, Anal. Chim. Acta 250, 21 (1991).

[7] Q. Huang, B. Paull, and P.R. Haddad, J. Chromatogr. A 770, 3 (1997).

[8] P.R. Haddad and N.E. Rochester, Anal. Chem. 60, 536 (1988).

[9] K. Gamoh and H. Sawamoto, Anal. Sci. 4, 665 (1988).

[10] R.G. Luthy and S.G. Bruce Jr, Environ. Sci. Technol. 13, 1481 (1979).

[11] J.K. Karchmer, Analytical Chemistry of Sulfur and Its Compounds (Wiley-Interscience, New York, 1970), p. 349.

[12] A. Kamyshny Jr, Limnol. Oceanogr.: Meth. 7, 442 (2009).

[13] A. Kamyshny Jr, C.G. Borkenstein, and T.G. Ferdelman, Geostand. Geoanal. Res. 33, 415 (2009).

[14] D.P. Kelly, L.A. Chambers, and P.A. Trudinger, Anal. Chem. 41, 898 (1969).

[15] L. Szekeres, Talanta 21, 1 (1974).

[16] L. Rong, L.W. Lim, and T. Takeuchi, Chromatographia 61, 371 (2005).

[17] A.K. Covington and R.A. Matheson, J. Solution Chem. 5, 781 (1976).

[18] G. Brauer, editor, Handbook of Preparative Inorganic Chemistry, 2nd ed. (Academic Press, New York, 1965), vol. 2.

[19] J.C. Goldman and J.J. McCarthy, Limnol. Oceanogr. 23, 695 (1978).

[20] J. Seeberg-Elverfeldt, M. Schluter, T. Feseker, and M. Kolling, Limnol. Oceanogr.: Meth. 3, 361 (2005).

[21] K. Naito, M.-C. Shien, and T. Okabe, Bull. Chem. Soc. Jpn 43, 1372 (1970).

[22] G.W. Luther, T.M. Church, J.R. Scudlark, and M. Cosman, Science 232, 746 (1986).

[23] J. Zopfi, T.G. Ferdelman, B.B. Jørgensen, A. Teske, and B. Thamdrup, Mar. Chem. 74, 29 (2001).

[24] J. Zopfi, T.G. Ferdelman and H. Fossing, in Sulfur Biogeochemistry - Past and Present: Geological Society of America, Special Paper 379, edited by J.P. Amend, K.J. Edwards and T.W. Lyons (Geological Society of America, 2004).

[25] L. Podgorsek and J.F. Imhoff, Aquat. Microb. Ecol. 17, 255 (1999).

[26] A. Kamyshny Jr, M. Zilberbrand, I. Ekeltchik, T. Voitsekovski, J. Gun, and O. Lev, Aquat. Geochem. 14, 171 (2008).

[27] A. Kamyshny Jr and T.G. Ferdelman, Mar. Chem. 121, 17 (2010).

[28] A. Bahta, G.A. Parker, and D.G. Tuck, Pure Appl. Chem. 69, 1489 (1997).

[29] N. Takeno, Atlas of Eh-pH diagrams: Geological Survey of Japan Open File Report No.419 (Geological Survey of Japan, 2005). <http://www.gsj.jp/GDB/openfile/files/no0419/ openfile419e.pdf>.

[30] K. Kolodsick and T. Ramstad, Anal. Chim. Acta 313, 75 (1995).

[31] P.A. Fagan and P.R. Haddad, J. Chromatogr. 550, 559 (1991). 